\title{
PROFIL DERMATITIS ATOPIK DI POLIKLINIK KULIT DAN KELAMIN RSUP PROF. DR. R.D KANDOU MANADO PERIODE JANUARI 2010 - DESEMBER 2012
}

\author{
${ }^{1}$ Juan P. E. Febriansyah \\ ${ }^{2}$ Grace M. Kapantow \\ ${ }^{2}$ Agus Hariyanto \\ Bagian/SMF Ilmu Kesehatan Kulit dan Kelamin Fakultas Kedokteran
Universitas Sam Ratulangi Manado
Email: ponce.juan86@yahoo.co.id
}

\begin{abstract}
Atopic dermatitis (AD) is a chronic and recurrent inflammatory disease most commonly found during infancy and childhood. This disease is very complex and has a variety of clinical manifestations. Its management depends not only on the medication, but also on skin care and avoidance of trigger factors. This study aimed to obtain the profile of atopic dermatitis at the Dermatovenerology Clinic of Prof. Dr. R. D. Kandou Hospital Manado period January 2010 to December 2012. This was a retrospective study using medical records of new registered patients at the Dermatovenerology clinic. New cases were grouped according to sex, age, occupation, treatment, and coinfection diseases. The results showed that there were $461(16.26 \%)$ new cases of $\mathrm{AD}$ out of 2,835 cases, consisted of 289 (62.69\%) females and $172(37.31 \%)$ males with a ratio of 1.7:1. The most frequent age group was $>12$ years old (58.35\%); they were commonly students (43.38\%). The most frequent treatment was a combination of oral antihistamin and topical corticosteroid (49.67\%). No coinfection was recorded among 332 cases (72.02\%). Conclusion: Most of the atopic dermatitis cases at the Dermatovenerology Clinic of Prof. Dr. R. D. Kandou Hospital Manado for the last 3 years were females, age group $>12$ years old, and as students. Combination of oral antihistamin and topical corticosteroid was the most common treatment. Almost all cases had no coinfection.
\end{abstract}

Keywords: atopic dermatitis, profile

\begin{abstract}
Abstrak: Dermatitis atopik (DA) merupakan penyakit peradangan kulit kronis dan residif yang sering terjadi pada masa bayi dan kanak-kanak. Penyakit ini sangat kompleks dengan gambaran klinis bervariasi. Penatalaksanaannya tidak hanya bergantung pada pengobatan, namun juga perawatan kulit dan menghindari faktor pencetus. Penelitian ini bertujuan untuk mendapatkan profil DA di Poliklinik Kulit dan Kelamin RSUP Prof. Dr. R. D. Kandou Manado periode Januari 2010 - Desember 2012. Metode penelitian ini retrospektif dengan menggunakan catatan medik pasien baru di Poliklinik Kulit dan Kelamin tersebut. Kasus baru dikelompokkan menurut jenis kelamin, usia, pekerjaan, pengobatan, dan penyakit penyerta. Hasil penelitian memperlihatkan 461 (16,26\%) kasus baru DA dari 2.835 kasus baru, terdiri dari 289 (62,69\%) perempuan dan 172 (37,31\%) laki-laki dengan rasio 1,7:1. Kelompok usia terbanyak ialah $>12$ tahun sebesar 269 (58,35\%), terbanyak pada pelajar/mahasiswa yaitu 200 kasus (43,38\%). Terapi tersering ialah kombinasi antihistamin oral dan kortikosteroid topikal sejumlah 229 kasus (49,67\%). Sejumlah 332 (72,02\%) kasus tidak disertai penyakit lain. Simpulan: Kasus dermatitis atopik di Poliklinik Kulit dan Kelamin RSUP Prof. Dr. R. D. Kandou Manado selama 3 tahun terakhir tersering pada perempuan, kelompok usia $>12$ tahun, dan pada pelajar/mahasiswa. Kombinasi anti histamin oral dan kortikosteroid topikal menjadi terapi yang tersering diberikan. Sebagian besar kasus tidak disertai penyakit lain.
\end{abstract}

Kata kunci: dermatitis atopik, profil 
Dermatitis atopik (DA) merupakan penyakit peradangan kulit kronik dan residif yang muncul paling sering selama masa bayi dan kanak-kanak. ${ }^{1}$ Penyakit ini sering disertai dengan riwayat atopi pada pasien sendiri atau keluarganya (DA, rinitis alergi, dan atau asma bronkial) disertai peningkatan IgE dalam serum. ${ }^{2}$

Pada orang dewasa prevalensi DA sekitar 1-3\%, dengan perbandingan lakilaki dan perempuan 1,3:1. Prevalensi DA pada anak-anak sebesar $10-20 \%$ di Amerika Serikat, Eropa Utara dan Barat, Afrika, Jepang, Australia, serta negara-negara industri lainnya. ${ }^{1,2}$ Angka kejadian DA cenderung meningkat 2-3 kali pada 30 tahun terakhir; pada anak-anak prevalensinya 5-15\% sedangkan pada dewasa 2-10 \%. Di Amerika Serikat, prevalensi DA pada dewasa $0,9 \% .^{2,3}$ Penelitian yang dilakukan Williams et al. terhadap 463.801 anak-anak dari 56 negara mendapatkan prevalensi DA bervariasi dari 0,6\% sampai 20,5\%. ${ }^{2} \quad$ Berdasarkan penelitian yang dilakukan di RSUD Dr. Soetomo Surabaya pada tahun 2005, didapatkan kelompok usia terbanyak 25-44 tahun $(22 \%){ }^{3}$ Dermatitis atopik sangat jarang terjadi pada usia tua ( $>50$ tahun). ${ }^{2}$

Secara klinis DA dapat dibagi menjadi fase infantil (usia 0-2 tahun), fase anakanak (usia 2-12 tahun), serta fase remaja dan dewasa (usia $>12$ tahun). Pada DA infantil, lesi mengenai daerah pipi, dahi, bahkan dapat meluas ke tempat lain yaitu skalp, leher, pergelangan tangan, lengan dan tungkai. Dermatitis atopik fase anakanak dapat merupakan kelanjutan fase infantil atau timbul sendiri (de novo). ${ }^{4}$ Letak kelainan kulit pada lipat siku, lipat lutut, pergelangan tangan, leher, dan terutama bagian fleksor; distribusi biasanya simetris. Pada DA fase remaja, lokalisasi lesi ialah lipat siku, lipat lutut, samping leher, dan sekitar mata, sedangkan pada DA fase dewasa, lesi dapat berupa plak papular-eritematosa dan berskuama. Distribusi lesi sering mengenai tangan dan pergelangan tangan, bibir, vulva, puting susu, atau skalp. ${ }^{4}$

Dermatitis atopik masih merupakan masalah kesehatan umum utama di dunia karena sangat kompleks, gambaran klinis yang sangat bervariasi, serta piñatalaksanaannya yang tidak hanya bergantung pada pengobatan, namun juga perawatan kulit dan menghindari faktor pencetus. Penatalaksanaan DA ditujukan untuk mengurangi tanda dan gejala penyakit, serta mencegah/mengurangi kekambuhan sehingga dapat mengatasi penyakit dalam jangka waktu lama serta mengubah perjalanan penyakit. $^{5}$

Komplikasi yang paling sering terjadi pada DA ialah infeksi sekunder yang disebabkan oleh Staphylococcus aureus. Umumnya, prognosis DA relatif baik karena tidak mengancam kehidupan namun secara fungsional kualitas hidup terganggu baik akibat gatal yang hebat, kekambuhan, maupun gangguan estetika bagi pasiennya. ${ }^{2}$

\section{METODE PENELITIAN}

Penelitian dilakukan secara retrospektif berdasarkan catatan medik pasien baru dermatitis atopik di Poliklinik Kulit dan Kelamin RSUP Prof. Dr. R. D. Kandou Manado selama 3 tahun sejak Januari 2010 sampai Desember 2012. Data primer yang didapatkan ialah hasil evaluasi berdasarkan jumlah pasien baru yang ditemukan, jenis kelamin, usia, pekerjaan, jenis penyakit penyerta yang ditemukan bersama dengan dermatitis atopic, dan pengobatan.

\section{HASIL PENELITIAN}

Jumlah seluruh kasus baru DA yang berobat di Poliklinik Kulit dan Kelamin BLU RSUP Prof Dr. R. D. Kandou, Manado selama periode 3 tahun (Januari 2010 - Desember 2012) sebanyak 461 kasus (16,26\%) yang memperlihatkan peningkatan setiap tahunnya yaitu: 137 kasus (14,91\%) tahun 2010; 160 kasus (17,62\%) tahun 2011; dan 164 kasus (16,27\%) tahun 2012 (Tabel 1).

Berdasarkan jenis kelamin, didapatkan bahwa perempuan lebih banyak dibandingkan laki-laki, yaitu 289 orang (62,69\%) perempuan dan 172 orang $(37,31 \%)$ lakilaki, dengan rasio 1,7:1 (Tabel 2). 
Tabel 1. Sebaran berdasarkan jumlah kasus baru DA di Poliklinik Kulit dan Kelamin RSUP Prof. Dr. R. D. Kandou Manado periode 2010 2012

\begin{tabular}{ccc}
\hline Tahun & \multicolumn{2}{c}{ Jumlah Kasus } \\
\cline { 2 - 3 } & DA (\%) & $\begin{array}{c}\text { Penyakit kulit dan } \\
\text { kelamin }\end{array}$ \\
\hline 2010 & $137(14,91)$ & 919 \\
2011 & $160(17,62)$ & 908 \\
2012 & $164(16,27)$ & 1008 \\
Jumlah & $461(16,26)$ & 2835 \\
\hline
\end{tabular}

Berdasarkan stadium klinik, DA terbanyak dijumpai pada kelompok usia $>12$ tahun (fase dewasa) sebanyak 269 kasus (58,35\%), diikuti oleh kelompok usia 3-12 tahun (fase anak) sebanyak 135 kasus (29,28\%), serta kelompok usia 0-2 tahun (fase bayi) sebanyak 57 kasus (12,36\%) (Tabel 3).

Berdasarkan jenis pekerjaan yang dijumpai pada pasien DA terbanyak ialah pelajar atau mahasiswa yaitu 200 pasien (43,38\%) diikuti oleh tidak bekerja 127 pasien $(27,55 \%)$ dan swasta 55 pasien (11,93\%) (Tabel 4).

Tabel 2. Sebaran berdasarkan jenis kelamin dermatitis atopik di Poliklinik Kulit dan Kelamin RSUP Prof. Dr. R. D. Kandou Manado periode 2010 - 2012

\begin{tabular}{ccccc}
\hline \multirow{2}{*}{ Tahun } & \multicolumn{2}{c}{ Jenis Kelamin } & & \\
\cline { 2 - 3 } & Perempuan & Laki-laki & Jumlah & $\%$ \\
\hline 2010 & 88 & 49 & 137 & 29,72 \\
2011 & 97 & 63 & 160 & 34,71 \\
2012 & 104 & 60 & 164 & 35,57 \\
Jumlah (\%) & $289(62,69)$ & $172(37,31)$ & 461 & 100 \\
\hline
\end{tabular}

Tabel 3. Sebaran berdasarkan kelompok usia dermatitis atopik berdasarkan stadium/fase klinik di Poliklinik Kulit dan Kelamin RSUP Prof. Dr. R. D. Kandou Manado periode 2010 - 2012

\begin{tabular}{ccccc}
\hline \multirow{2}{*}{$\begin{array}{c}\text { Kelompok Usia } \\
\text { (tahun) }\end{array}$} & \multicolumn{3}{c}{ Tahun } & \multirow{2}{*}{ Jumlah (\%) } \\
\cline { 2 - 4 } & $2010(\%)$ & $2011(\%)$ & $2012(\%)$ & \\
\hline $0-2($ Fase bayi) & $18(13,14)$ & $14(8,75)$ & $25(15,24)$ & $57(12,36)$ \\
$3-12$ ( Fase anak) & $31(22,63)$ & $61(38,12)$ & $43(26,22)$ & $135(29,28)$ \\
$>12$ (Fase dewasa) & $88(64,23)$ & $85(53,13)$ & $96(58,54)$ & $269(58,36)$ \\
Jumlah & $137(100)$ & $160(100)$ & $164(100)$ & $461(100)$ \\
\hline
\end{tabular}

Tabel 4. Sebaran berdasarkan jenis pekerjaan pasien dermatitis atopik di Poliklinik Kulit dan Kelamin RSUP Prof. Dr. R.D. Kandou Manado periode 2010 - 2012

\begin{tabular}{ccccc}
\hline \multirow{2}{*}{ Jenis Pekerjaan } & \multicolumn{3}{c}{ Tahun } & \multirow{2}{*}{ Jumlah (\%) } \\
\cline { 2 - 4 } & $2010(\%)$ & $2011(\%)$ & $2012(\%)$ & \\
\hline Pelajar/mahasiswa & $64(46,71)$ & $74(46,25)$ & $62(37,80)$ & $200(43,38)$ \\
Tidak bekerja & $32(23,36)$ & $43(26,88)$ & $52(31,71)$ & $127(27,55)$ \\
Swasta & $15(10,95)$ & $19(11,88)$ & $21(12,81)$ & $55(11,93)$ \\
Pegawai negeri sipil & $14(10,22)$ & $8(5,00)$ & $22(13,41)$ & $44(9,55)$ \\
Ibu rumah tangga & $12(8,76)$ & $9(5,62)$ & $5(3,05)$ & $26(5,64)$ \\
Petani & 0 & $7(4,37)$ & $2(1,22)$ & $9(1,95)$ \\
Jumlah & $137(100)$ & $160(100)$ & $164(100)$ & $461(100)$ \\
\hline
\end{tabular}

Berdasarkan jenis penyakit penyerta yang ditemukan bersamaan dengan DA, didapatkan sebanyak 332 (72,02\%) pasien DA yang tidak disertai penyakit penyerta dan 129 (27,98\%) pasien DA disertai penyakit penyerta. Jenis penyakit penyerta yang paling sering ialah infeksi bakteri sebanyak 91 pasien (19,74\%) (Tabel 5). 
Jenis pengobatan yang terbanyak digunakan adalah kombinasi anti histamin dan kortikosteroid topikal sejumlah 229 (49,67\%), diikuti kombinasi antihistamin

oral, antibiotik oral/topikal dan kortikosteroid topikal sebanyak $151 \quad(32,76 \%)$ (Tabel 6).

Tabel 5. Sebaran berdasarkan jenis penyakit penyerta yang ditemukan bersamaan dengan DA di Poliklinik Kulit dan Kelamin RSUP Prof. Dr. R. D. Kandou Manado periode 2010 - 2012

\begin{tabular}{ccccc}
\hline Jenis penyakit penyerta yang & \multicolumn{3}{c}{ Tahun } & \multirow{2}{*}{ Jumlah (\%) } \\
\cline { 2 - 4 } ditemukan bersamaan dengan DA & $2010(\%)$ & $2011(\%)$ & $2012(\%)$ & \\
\hline Infeksi bakteri & $34(24,82)$ & $29(18,13)$ & $28(17,07)$ & $91(19,74)$ \\
Infeksi virus & $2(1,46)$ & 0 & 0 & $2(0,43)$ \\
Infeksi jamur & $9(6,57)$ & $7(4,38)$ & $16(9,76)$ & $32(6,94)$ \\
Eritroderma & $2(1,46)$ & $1(0,62)$ & $1(0,61)$ & $4(0,87)$ \\
Tidak disertai penyakit penyerta & $90(65,69)$ & $123(76,87)$ & $119(72,56)$ & $332(72,02)$ \\
Jumlah & $137(100)$ & $160(100)$ & $164(100)$ & $461(100)$ \\
\hline
\end{tabular}

Tabel 6. Sebaran berdasarkan jenis pengobatan dermatitis atopik di Poliklinik Kulit dan Kelamin RSUP Prof. Dr. R. D. Kandou, Manado periode 2010 - 2012

\begin{tabular}{ccccc}
\hline \multirow{2}{*}{ Terapi yang diberikan } & \multicolumn{3}{c}{ Tahun } & \multirow{2}{*}{ Jumlah $(\%)$} \\
\cline { 2 - 4 } & $2010(\%)$ & $2011(\%)$ & $2012(\%)$ & \\
\hline AH + ABO/ABT + KST & $45(32,85)$ & $55(34,38)$ & $51(31,10)$ & $151(32,76)$ \\
AH + KST & $62(45,25)$ & $81(50,62)$ & $86(52,44)$ & $229(49,67)$ \\
KST & $9(6,57)$ & $6(3,75)$ & $7(4,27)$ & $22(4,77)$ \\
AH + Pelembab & $21(15,33)$ & $18(11,25)$ & $20(12,19)$ & $59(12,80)$ \\
Jumlah & $137(100)$ & $160(100)$ & $164(100)$ & $461(100)$ \\
\hline
\end{tabular}

Ket: AH (Anti histamin oral); ABO (Antibiotik oral); ABT (Antibiotik topikal); KST (Kortikosteroid topikal)

\section{BAHASAN}

Pada penelitian ini didapatkan jumlah kasus DA selama 3 tahun (1 Januari 2010 31 Desember 2012) sejumlah 461 kasus $(16,26 \%)$ dari seluruh kasus baru (2.835 kasus) di Poliklinik Kulit dan Kelamin RSUP Prof. Dr. R. D. Kandou Manado (Tabel 1).

Hasil penelitian ini menunjukkan bahwa terjadi peningkatan 4-5 kali lipat berdasarkan hasil penelitian Setyaningrum dan Hutomo di Unit Rawat Jalan RSUD Dr. Soetomo Surabaya pada tahun 2003-2005 dengan jumlah kasus DA sekitar 3,5\%, ${ }^{2,3}$ dan hasil penelitian Rambing di Poliklinik Kulit dan Kelamin RSUP Prof. Dr. R. D. Kandou Manado pada tahun 2006-2008 dengan jumlah kasus DA sekitar 3,2\%; dan terjadi peningkatan 2 kali lipat berdasarkan catatan medis di Poliklinik Kulit dan Kelamin FKUI/RSCM Jakarta tahun 1996 dengan sekitar 7,6\% kasus baru DA. ${ }^{6}$ Berdasarkan data di Poli Kulit Anak RSUD Dr. Soetomo Surabaya, penelitian Putra et al. tahun 2010 mendapatkan peningkatan jumlah penderita DA setiap tahunnya. ${ }^{7}$ Penyebab peningkatan prevalensi DA tidak diketahui dengan pasti. Beberapa faktor risiko yang mungkin dapat dihubungkan dengan peningkatan penyakit atopik yaitu ukuran keluarga yang kecil, peningkatan pendapatan dan pendidikan, migrasi dari lingkungan pedesaan ke perkotaan, dan meningkatnya penggunaan antibiotik. ${ }^{1}$

Berdasarkan sebaran jenis kelamin pada penelitian ini didapatkan rasio perempuan:laki-laki sebesar 1,7:1 (Tabel 2). Hal ini tidak jauh berbeda dengan 
penelitian oleh Setyanto dan Suyoso di Unit Rawat Jalan Penyakit Kulit dan Kelamin RSUD Dr. Soetomo Surabaya pada tahun 1999 dengan perbandingan perempuan dan laki-laki $1,3: 1 .^{8}$

Pada sebaran kelompok usia berdasarkan stadium/fase klinik DA terbanyak pada kelompok usia $>12$ tahun (fase dewasa) yaitu 269 kasus (58,35\%) (Tabel 3). Hasil penelitan ini sesuai dengan penelitian yang dilakukan oleh Rambing di Poliklinik Kulit dan Kelamin RSUP Prof. Dr. R. D. Kandou Manado periode Januari 2006- Desember 2008 yang mendapatkan DA terbanyak pada kelompok usia $>12$ tahun $(81,8 \%){ }^{2}$ dan juga sesuai dengan penelitian yang dilakukan Setyaningrum dan Hutomo di Divisi Alergi Unit Rawat Jalan Penyakit Kulit dan Kelamin RSUD Dr. Soetomo Surabaya pada periode 20002002 dimana kasus terbanyak pada kelompok usia $\geq 12$ tahun (54,8 \%).

Berdasarkan sebaran jenis pekerjaan, pada penelitian ini kasus terbanyak ialah pelajar/mahasiswa yaitu 200 kasus (43,38\%) diikuti oleh yang tidak bekerja (27,55\%), swasta (11,93\%), pegawai negeri sipil (9,55\%), ibu rumah tangga (5,64\%), dan petani (1,95\%) (Tabel 4). Pekerjaan sangat berpengaruh terhadap kekambuhan DA, terutama berhubungan dengan paparan terhadap faktor pencetus, baik melalui hirupan maupun kontak.,9 Evaluasi sulit dilakukan karena tidak diketahui jenis pekerjaan yang spesifik berkaitan dengan paparan dugaan faktor pencetus. ${ }^{3}$

Berdasarkan sebaran jenis penyakit penyerta yang ditemukan bersamaan dengan DA didapatkan sebanyak 332 (72,02\%) kasus DA yang tidak disertai penyakit lain dan 129 (27,98\%) pasien DA yang disertai penyakit lain (Tabel 5). Jenis penyakit penyerta yang tersering ialah infeksi bakteri sebanyak 91 kasus (19,74\%), diikuti oleh infeksi jamur 32 kasus (6,94\%). Berdasarkan acuan pustaka, infeksi sekunder bakteri yang paling sering ditemukan pada DA ialah infeksi Streptococcus $\quad \beta$-hemolyticus atau Staphylococcus. Kepekaan terhadap infeksi jamur dipengaruhi oleh gangguan fungsi sawar epidermis, kelembaban, dan maserasi. $^{5}$

Berdasarkan sebaran jenis pengobatan DA, yang terbanyak digunakan ialah kombinasi anti histamin dan kortikosteroid topikal sejumlah 229 kasus (49,67\%), diikuti kombinasi antihistamin oral, antibiotik oral/topical, dan kortikosteroid topikal sebanyak 151 (32,76\%). Hasil penelitian ini tidak sesuai dengan penelitian Rambing di Poliklinik Kulit dan Kelamin di RSUP Prof. Dr. R. D. Kandou Manado periode Januari 2006 - Desember 2008, dimana jenis pengobatan terbanyak ialah bentuk kombinasi antihistamin, antibiotik oral, dan kortikosteroid topikal. ${ }^{2}$ Penatalaksanaan DA dapat berupa pemberian pengobatan yang bersifat sistemik maupun topikal. Pemberian terapi sistemik dapat menggunakan antihistamin, kortikosteroid, dan antibiotika sedangkan yang bersifat topikal biasanya ditujukan untuk mengatasi manifestasi kulit yang terjadi, dapat berupa pemberian pelembab dan kortikosteroid topikal. ${ }^{2,3,10}$ Biasanya pasien diberikan terapi kombinasi untuk dapat menanggulangi berbagai keluhan terutama rasa gatal. Pemberian antibiotika terutama untuk lesi yang mengalami infeksi. ${ }^{2}$

\section{SIMPULAN}

Studi retrospektif di Poliklinik Kulit dan Kelamin RSUP Prof Dr. R. D. Kandou Manado periode 1 Januari 2010 sampai dengan 31 Desember 2012 mendapatkan 461(16,26\%) kasus baru dermatitis atopik dari 2.835 jumlah keseluruhan kasus. Kasus dermatitis atopik tersering dialami oleh perempuan dibandingkan laki-laki dengan perbandingan 1,7:1. Kasus terbanyak ditemukan pada kelompok usia $>12$ tahun, pekerjaam pelajar/mahasiswa, dan tidak disertai penyakit lainnya. Pengobatan terbanyak ialah kombinasi antihistamin oral dan kortikosteroid topikal.

\section{SARAN}

1. Diperlukan penelitian lebih lanjut mengenai insiden dan epidemiologi DA agar dapat memberikan gambaran 
yang lebih akurat mengenai profil DA serta faktor-faktor yang memengaruhinya.

2. Diperlukan sistem pendataan pasien yang lebih rinci, lengkap, dan informatif untuk mendapatkan gambaran yang lebih jelas mengenai jenis pekerjaan.

\section{DAFTAR PUSTAKA}

1. Leung DYM, Eichenfield LF, Boguniewicz M. Atopic dermatitis atopic eczema. In: Wolff K, Goldsmith LA, Katz SI, Gilchrest BA, Paller AS, Leffell DJ, editors. Fitzpatrick's Dermatology in General Medicine (8th ed.). New York: McGraw Hill, 2012; p. 165-82.

2. Rambing IRJ. Profil dermatitis atopik di Poliklinik Kulit dan Kelamin BLU RSUP Prof. Dr. R. D. Kandou Manado periode Januari 2006 - Desember 2008 [KTIS]. Manado: Fakultas Kedokteran Universitas Sam Ratulangi, 2009.

3. Setyaningrum T, Hutomo $M$. Dermatitis atopik di Divisi Alergi URJ Kulit dan Kelamin RSUD Dr. Soetomo Surabaya 2000-2002. Berkala Ilmu Penyakit Kulit dan Kelamin. 2005;17(1):14-26.

4. Sularsito SA, Djuanda S. Dermatitis atopik. In: Djuanda A, Hamzah M, Aisah S, editors. Ilmu Penyakit Kulit dan Kelamin (4th ed.). Jakarta: BP FKUI, 2006; p. 138-47.
5. Sugito TL, Boediardja SA, Wisesa TW, Prihianti S, Agustin T, editors. Buku Panduan Dermatitis Atopik Diagnosis dan Tatalaksana. Jakarta: BP FKUI, 2011.

6. Surakarta IK, Aisah S, Sugito TL. Alergen susu sapi sebagai faktor risiko dermatitis atopik pada balita. Media Dermatovenereologica Indonesia. 2000;27:15763.

7. Putra IGND, Rahmadewi, Ervianti E, Zulkarnain I. Profil kadar IgE spesifik terhadap malassezia furfur pada berbagai derajat keparahan dermatitis atopik anak di RSUD Dr. Soetomo Surabaya. Berkala Ilmu Penyakit Kulit dan Kelamin. 2010;22 (2):114-20.

8. Setyanto B, Suyoso S. Kepadatan pityrosporum ovale pada lesi di wajah dan/ atau leher penderita dermatitis atopik. Media Dermato-venereologica Indonesia. 2000;27: 164-8.

9. Boediardja SA. Peran staphylococcus aureus pada dermatitis atopik dan penatalaksanaannya. Media Dermatovenereologica Indonesia. 2000;28:315S319S.

10. Suwarsa O. Dermatitis atopik. In: Dahlan Z, Kartasasmita CB, Supandiman I, Sumarman I, Djajakusumah TS, editors. Penatalaksanaan Alergi Imunologi, Bandung: Perhimpunan Alergi Imunologi Indonesia Cabang Bandung, 2010; p. 265-78. 